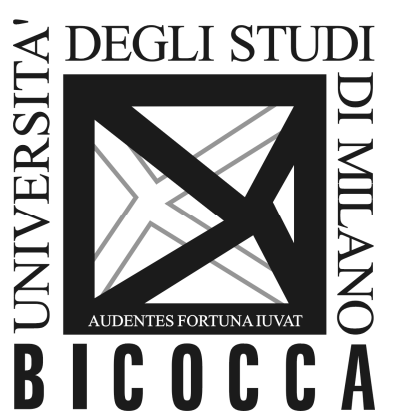

\author{
DEPARTMENT OF ECONOMICS, \\ MANAGEMENT AND STATISTICS \\ UNIVERSITY OF MILAN - BICOCCA
}

DEMS WORKING PAPER SERIES

\title{
The deterrence effect of real-world operational tax audits
}

Gabriele Mazzolini, Laura Pagani, Alessandro Santoro

No. 359 - January 2017

Dipartimento di Economia, Metodi Quantitativi e Strategie di Impresa Università degli Studi di Milano - Bicocca

http://dems.unimib.it/ 


\title{
The deterrence effect of real-world operational tax audits
}

\author{
By Gabriele Mazzolini, Laura Pagani And Alessandro SANTORO ${ }^{1 *}$
}

\begin{abstract}
We use a large administrative tax-returns panel dataset merged with tax audit database to estimate the effect of real-world operational tax audits on subsequent tax behavior. Our identification strategy and the institutional setting that we consider enable us to address potential endogeneity related to non-random selection of taxpayers to be audited. We find a positive and lasting effect of audits on subsequent reported income. However, in line with theoretical predictions, taxpayers do not increase tax compliance when the tax authority does not assess a positive additional income. Our results are robust to a variety of specifications and samples.
\end{abstract}

Keywords: Tax Compliance, Administrative Panel Data, Tax Audits JEL Code: H26; C23; C55

\footnotetext{
* Mazzolini: Department of Economics, Management and Statistics (DEMS), Università di Milano Bicocca, Piazza Ateneo Nuovo, 1, 20126 Milan, Italy (e-mail: gabriele.mazzolini@unimib.it); Pagani: Department of Economics, Management and Statistics (DEMS), Università di Milano Bicocca, Piazza Ateneo Nuovo, 1, 20126 Milan, Italy (e-mail: laura.pagani@unimib.it); Santoro: Department of Economics, Management and Statistics (DEMS), Università of Milano Bicocca, Piazza Ateneo Nuovo, 1, 20126 Milan, Italy, and Dondena, Università Bocconi (e-mail: alessandro.santoro@unimib.it). This paper is part of a common research project between DEMS and the Italian Revenue Agency. We are particularly thankful to Dr. Stefano Pisani and to the Research Unit at the Italian Revenue Agency for providing us with the dataset and with suggestions and clarifications on the nature and interpretation of the data. The usual disclaimers apply.
} 
In the benchmark economic model of tax-compliance, utility maximizing taxpayers decide the level of income to report considering the private costs and benefits of evasion. Compliance depends on evasion detection probability and on related penalties (Allingham and Sandmo, 1972).

Subsequent research has questioned this framework on the grounds that it does not consider all motivations for tax compliance, suggesting that behavioral aspects are relevant as well. These latter refer to "tax morale" or "intrinsic motivation", which is a broad concept comprising a set of non-pecuniary factors affecting tax compliance, such as desire to comply with the law, feelings of guilt and shame when not complying, reciprocity when tax payments are made in exchange for public services, peer effects and long-run cultural factors (Luttmer and Singhal, 2014). This intrinsic willingness to pay may help to explain the empirical evidence of high tax compliance despite low actual detection probabilities and penalties.

However, research on tax compliance has highlighted that the observed tax behavior may be related also to the close-to-one probability of detection in the presence of third-party reporting (Kleven et. al, 2011). In line with this, Dwenger et al. (2016) show that in a zero-deterrence scenario 80 percent of individuals evade taxes, suggesting that the large majority of them behave as rational expected-utility maximizers. Actual tax compliance may be higher than that predicted by the utilitymaximizing deterrence model also if taxpayers, despite being rational, overestimate detection probability and penalties (Chetty, 2009).

The conclusions that we can draw from the literature on tax compliance is that the latter is shaped by both economic incentives related to deterrence and intrinsic motivations. Yet these latter are more difficult for tax authorities to influence, especially in the short term. In this paper, we consider the main deterrence instrument: tax audits. We focus in particular on those audits conducted by revenue agencies during their customary auditing activity and which, following Slemrod (2016), we call 'real-world operational audits'. 
Tax audits produce two effects on tax compliance (Gemmel and Ratto, 2012). First, when noncompliance is detected, taxpayers are forced to comply and an additional tax yield is raised. Second, audits may generate a change in subsequent tax behavior by both audited (deterrence effect) and non-audited (spillover effect) taxpayers.

The deterrence effect occurs when audits induce audited taxpayers to revise upward their perceived probability of being detected in the future. This perceived probability, in its turn, is the product of the probability of being audited again and the probability of undeclared income being uncovered conditional on audit. This upward revision may occur for two reasons. First, because taxpayers positively update the perceived probability of being audited in the future if they believe that they have become a target of enforcement initiatives. We call this the 'target effect'. Second, if taxpayers are contacted by tax inspectors principally when these latter believe that evasion can be uncovered, audited taxpayers are also likely to revise upward their perceived probability of the tax authority being successful in discovering evasion when carrying out an audit. As a result, taxpayers experiencing an audit are likely to increase their perceived probability of detection (Kleven et al., 2011). In the expected utility maximizing model of tax-compliance, this probability update will lead to an increase in future reporting.

In this study, we contribute to the literature on the effects of audits on subsequent tax compliance by audited taxpayers. We test whether tax behavior following a real-world operational audit is consistent with the prediction of the standard economic model of tax evasion that compliance increases after an audit. We do so by using an administrative tax-returns panel dataset of 528,540 Italian taxpayers whose income is obtained from self-employment and from sole proprietorships merged with a tax audit database, both made available by the Italian revenue agency. 
Thanks to the recent wider availability of confidential taxpayers' administrative datasets and to the willingness of some revenue authorities to conduct field experiments to evaluate the effect of audits, there is a growing body of literature analyzing the deterrence causal effect of audits on taxpayer behavior using randomized audits. Overall, this literature has found a positive and significant effect of audits on subsequent tax compliance, although the magnitude is both heterogeneous across income types and time-variant. Kleven et al. (2011) conducted a tax-enforcement field experiment in Denmark and found that the overall effect of audits on total net income is positive but quite modest and driven entirely by self-reported income. DeBacker et al. (2015a) used IRS data and found that on average audits cause a 0.4 percent increase of reported wage income over three years after the audit. The effect is much higher when considering selfemployment income (7.5\%). Advani et al. (2015) used random audits in the United Kingdom. They found a large and persistent impact of audits on reported tax liability that reached a remarkable 26 percent increase four years after the audit.

The previous studies are based on random audits. These latter have undoubtedly the methodological advantage over real-world operational audits that derives from the randomness of treatment assignment. Then, the internal validity of these studies cannot be questioned. Nevertheless, if the objective of the empirical analysis is to explore the effect of audits on subsequent tax behavior, the use of random audits suffers from two limitations (Slemrod, 2016).

The first and most important limitation from the theoretical point of view is that, with the exception of Kleven et al. (2011), in this literature taxpayers are aware that they have been randomly selected to be audited for research reasons. As said above, the reaction of taxpayers to an audit is related to the upward revision of their prior probability of being detected. However, taxpayers' awareness of having been audited only because they are part of a study implies in and of itself that they may revise the audit risk differently from the case in which they think that they have 
been chosen by the tax authority for an operational audit. This implies that one of the channels related to the process of probability updating, i.e. the target effect, may act differently from how it operates in the case of real-world operational audits.

Second, from a more policy-oriented perspective, randomly selected taxpayers are not representative of the taxpayers that are normally targeted by tax authorities. Consequently, their behavior after audits may be different from that of taxpayers subject to real-world operational audits. Trying to estimate the change in reported income in the years following an audit as realistically as possible is crucial for a correct cost-benefit analysis of enforcing activities implemented by the tax authority.

Our paper is the first to measure the impact of individual tax audits using realworld operational audits rather than random audits. ${ }^{2}$ It is indubitable that, despite the above-mentioned limitations of random audits, real-world audits pose a potential threat to a causal interpretation of estimates because audit assignment may be not random. To address this point and to study the causal effect of real-world audits on subsequent tax behavior, our identification strategy relies on differencein-difference comparison with non-audited taxpayers. We compare changes in outcome between taxpayers who received the audit (the treated group) and taxpayers who were not subject to the audit (the control group). Moreover, we use a semiparametric ex-ante approach restricting our control sample using Abadie et. al.'s (2004) nearest-neighbor matching algorithm. This empirical strategy enables us to address endogeneity related to time-invariant factors influencing treatment assignment.

An additional concern is that time-variant individual characteristics may affect treatment assignment. However, in the specific Italian institutional setting, we do

\footnotetext{
2 DeBacker et al. (2015b) study the impact of operational audits on corporations. However, the tax behavior of corporations is likely to depend not only on deterrence and intrinsic motivations, but also on incentives provided within the agency contract between the principal (i.e. the shareholders) and the agent (i.e. the managers) (Slemrod, 2004).
} 
not believe that this is a threat for identification. Our data show that in Italy audits carried out in a given year are largely concentrated on tax returns referring to four or five years before, which is just before evasion becomes no longer prosecutable (after five years). Moreover, we show that neither income nor other time-variant potential outcome variables are significantly related to the probability of being selected for an audit in a given year. This evidence suggests that in the Italian context there are no individual time-variant factors that affect the probability of being audited. Then, our empirical analysis has the advantages related to the use of real-world operational audits, without apparently suffering from its methodological drawbacks. Nonetheless, we strengthen our identification strategy by providing neat evidence for the parallel trends assumption, and we complement our main analysis with some robustness checks. Overall, our main results are robust to a variety of specifications and samples.

Our dataset also allows a more thorough exploration of the taxpayer's process of beliefs updating. In the Italian auditing process, when the audit note is issued to the taxpayer, it contains a preliminary adjustment of the taxes due. The latter can be modified, and even totally cancelled, on the basis of new evidence. When the revenue agency recognizes that it has mistakenly claimed additional taxes and cancels the preliminary adjustment, we say that the audit has a 'null outcome' (alternatively, the initial adjustment remains positive). This case occurs if either the taxpayer has reported income truthfully and is able to prove it to the tax authority or, in contrast, she is particularly adept at hiding evasion. In the latter case, we expect a downward revision of the probability assigned by the cheating taxpayer to the success of tax inspectors in discovering evasion. According to the rational taxpayer model, on average the effect on future reported income should be lower than in the positive-adjustment case. Differently from the previous literature, we can test this hypothesis because in our data we observe the audit's outcome. 
We obtain three main results. First, we find that the deterrence effect of tax audits is positive and significant. Reported income increases on average by approximately 8.2 percent after audits. This result is in line with the prediction of the expected utility maximizing model of higher compliance following an upward revision of the audit probability. Second, we find a lasting impact of tax audits, which is still significant and positive up to three years after the audit. Finally, as expected, we find no effect in the case of null-outcome audits on average, although the first year effect is negative. Altogether, our results tend to reinforce the view of the taxpayer as a rational individual who increases tax compliance as a result of an increase in the perceived probability of being audited and in the perceived probability that undeclared income is detected conditional on audit.

An additional result that we obtain is that, on average, high reported-income taxpayers exhibit a lower change in tax compliance after an audit compared with low reported-income taxpayers, confirming the finding of Slemrod et al. (2001). This latter study interprets the result by assuming that high-income taxpayers are more likely to receive professional assistance with their tax affairs and, as a result, they are better able to hide evasion. Another possible explanation is that, due to the high progressivity of the Italian personal tax system, the marginal burden for increasing compliance is heavier for high-income earners. However, our data cannot be used to test these hypotheses.

A final point to stress is that, from the administration's viewpoint, actual efficiency rests on the cost/benefit analysis of audits. Based on our results and on additional information on the administrative costs of audits made available by the Italian revenue agency, we conclude our paper with a back of the envelope calculation of the net tax-revenue effect of audits. We find a positive and sizeable effect.

The paper proceeds as follows. Section I describes the Italian institutional background and the tax reporting and auditing scheme. Section II describes the 
data. Section III describes the methods. Section IV contains estimates of the impact of audits on subsequent tax behavior. Section V provides robustness checks. Section VI presents an estimate of the net tax-revenue effect of audits. Section VII draws some conclusions and indicates directions for future research.

\section{Tax administration in Italy}

In Italy, individual taxpayers are required to pay taxes yearly on all personal incomes earned in each tax year. The latter is based on the calendar year. Incomes earned in a given tax year have to be reported between May and September of the following calendar year. For instance, incomes earned between January $1^{\text {st }}$ and December $31^{\text {st }}$ of year $\mathrm{t}-1$ have to be reported between May and September of year $\mathrm{t}$ (see Figure 2). Personal incomes may derive from dependent work, selfemployment, sole proprietorship and capital (shares in a partnership or in a corporation).

After incomes are declared, tax reports can be audited. The Italian revenue agency (Agenzia delle Entrate, henceforth AE) can audit tax reports for up to five years (ordinary expiration period) after the end of the calendar year to which the declaration refers. Then, after five years, evasion can no longer be prosecuted unless it is the outcome of a fraud or a criminal act, in which case the expiration period may be longer.

Each year the central directorate of the AE sets specific targets in terms of the number and types of taxpayers to be audited. It uses various public and private databases to assess audit risk. However, both regional and provincial directorates possess a remarkable degree of autonomy in the selection of the taxpayers to be audited. They can conduct their own risk assessment, based on information collected on the spot, and identify risky taxpayers not selected at the central level. Business Sector Studies (Studi di Settore, SDS, see Santoro and Fiorio, 2011) are 
an important source of information for the AE. For each taxpayer subject to SDS, a presumptive revenue (i.e. value of sales) is computed by multiplying the input values (reported by the taxpayer) by the input productivity as computed by the AE. This latter is obtained by regressing revenues on input values reported by a subset of taxpayers belonging to the same cluster as the taxpayer under consideration and who are classified as reliable by the $\mathrm{AE} .^{3}$ In contrast, costs are not directly considered during this process.

Audits generate an audit notice which contains the preliminary tax adjustment claimed by the AE. Note that an audit notice can refer to multiple taxes (for example, to both income and value added taxes), but in this paper we consider only adjustments referring to personal income tax. The preliminary adjustment is subject to further scrutiny. Based on new information, the AE can repeal the legal act and formally declare that the taxpayer is compliant (with respect to the specific claim that occasioned the assessment). We call this case 'null-outcome audit'. In the other case, there is a positive adjustment, which is generally of the same amount as the preliminary adjustment. The taxpayer can accept this adjustment. If she does not, the audit process may continue in two ways. The first is a demand for a settlement whereby the $\mathrm{AE}$ and the taxpayer engage in a sort of bargaining process and the $\mathrm{AE}$ gives up a part of the positive adjustment. The taxpayer immediately pays the tax debt, so that the AE saves on administrative costs related to tax collection. The second way in which the process may continue is through a legal dispute against the audit note whereby the case is brought before a special tax court. The procedure can last for various years before being legally established. The final outcome, which we do not observe in the data, can be a total or partial cancellation of the preliminary assessment. Figure 1 summarizes the full range of audit outcomes.

${ }^{3}$ The definition of "reliability" is not disclosed by AE, so that no collusion can affect the input productivity estimates. 


\section{[ Insert Figure 1 Here ]}

\section{Data}

We analyze a perfectly balanced panel of Italian taxpayers using data from two sources, both released by the AE. The first dataset (that we call 'AT') contains information from the Tax Return Register "Anagrafe Tributaria", which includes the tax reports of all Italian taxpayers. The available sample comprises the universe of VAT registered taxpayers with legal residence in three of the most populated Italian regions, namely Lombardy (located in the North), Lazio (located in the Centre) and Sicily (located in the South), which account for around one third of the entire Italian population. VAT registered taxpayers usually obtain their income mainly from self-employment or from sole proprietorships. ${ }^{4}$ The sample includes 528,540 taxpayers observed for the 2007-2011 period, corresponding to 2,642,700 observations and to one third of the Italian population of taxpayers with income obtained mainly from self-employment and sole proprietorships. The kind of taxpayers included in our sample have a high opportunity to evade (Pissarides and Weber, 1989, Slemrod et al., 2001; Cabral et al., 2014) because most of their incomes are not subject to third-party reporting (Kleven et al., 2011). ${ }^{5}$

The AT contains information on a set of taxpayers' demographic characteristics, like gender, age and place of residence, as well as on the main characteristics of taxpayers' economic activity, like the sector and the number of dependent workers. It includes a range of tax-related variables taken from tax returns, like income type (from self-employment or sole proprietorship), incomes from various sources,

\footnotetext{
4 A VAT registered taxpayer, in a given year, may report (also) other types of income. For example, incomes that professionals obtain as members of company boards are treated, for tax purposes, as incomes from dependent work. This motivates our choice to take, as our main dependent variable, reported income obtained from self-employment and from sole proprietorships.

5 Although recent research has argued against the belief that employees do not evade (Best, 2014; Paulus, 2015), Kleven (2014), using data for more than 80 countries, shows a strong negative relationship between the tax take and the share of self-employed workers, consistent with the view that the coverage of third-party reporting is a crucial determinant of tax enforcement.
} 
personal income tax base, gross tax, total amount of tax allowances, net tax. The AT also contains information related to the implementation of SDS, in particular the presumptive revenues and whether taxpayers' revenues are higher than the presumptive value. ${ }^{6}$ However, this information is not available for around 20 percent of taxpayers because the SDS do not apply. Unfortunately, taxpayers with missing values on these variables are not randomly selected because taxpayers may self-qualify as SDS non-applicants by claiming to be in a 'non-normal' situation or may manipulate the value of presumptive revenue (Santoro and Fiorio, 2011), and the available data do not allow us to distinguish these cases. For this reason, we will not use SDS-based information throughout the empirical analysis.

The second source of data is the Tax Audit Database (TAD). For each audit, it contains information on the amount of the preliminary adjustment, the audit year and the outcome of the audit, distinguishing among null outcome, no taxpayer reaction, settlement, and legal dispute.

As regards the audit year, according to the AE definition a 'year $t$ ' audit is an audit carried out between July $1^{\text {st }}$ of year $\mathrm{t}-1$ and June $30^{\text {th }}$ of year $\mathrm{t}$. Taxpayers are immediately notified when an audit is opened. ${ }^{7} \mathrm{~A}$ 'year $\mathrm{t}$ ' audit overlaps with two tax years ( $\mathrm{t}-1$ and $\mathrm{t}$ ) and with two tax reports (referring to tax years $\mathrm{t}-2$ and $\mathrm{t}-1$, respectively). Note that tax reports referring to year $t$ are issued between May and September of year $\mathrm{t}+1$, thus after a 'year t' audit. Figure 2 summarizes the reporting and auditing time structure.

It is highly unlikely that a 'year t' audit has an impact on reports for tax year t-2, since this would require an audit to be conducted between July and September of

\footnotetext{
${ }^{6}$ Unfortunately, the AT dataset does not contain reliable information on reported revenues.

7 This is undoubtedly a great advantage of our data with respect to other papers. DeBacker et al. (2015a), for instance, observe the moment when an audit is opened and closed, but they do not know when the taxpayer is notified of the audit. They are therefore unable to observe precisely when taxpayers become aware that the treatment has been assigned and, accordingly, update the subjective detection probability. In our case, instead, we are sure that taxpayers can react to the treatment starting from the first tax return filed after an audit. On the other hand, we do not observe the exact date on which the audit is conducted, but only the interval, i.e. the audit year as previously defined.
} 
year $\mathrm{t}-1$, which rarely occurs. In contrast, a 'year t' audit may have an impact on reports for tax year $\mathrm{t}-1$, since the corresponding report has probably been issued after the audit. However, tax year t-1 may be already concluded, and this limits the adjustment margins for the taxpayer. Note that the taxpayers we observe usually adopt a simplified accounting system that is of limited relevance for tax purposes. This means that, even after the tax year has concluded, tax reports can be modified and not fully adhere to the accounting registrations actually made during the year. Thus, some incomes not recorded in the accounting books can emerge later in the tax report. Finally, a 'year t' audit is very likely to have an impact on tax reports referring to tax year $\mathrm{t}$, since the audit is conducted before the tax year has concluded and thus before the tax report referring to tax year $\mathrm{t}$ is issued.

\section{[ Insert Figure 2 Here ]}

In view of the audit's above-described temporal structure, we will check for the impact of a 'year t' audit starting from reports referring to tax year $\mathrm{t}-1$, although we expect a lower impact in the first year since the audit may be conducted when the tax year has already concluded.

The AT and the TAD datasets are merged using an encoded taxpayer number (to ensure anonymity) and the tax year. In our sample period, 17,472 taxpayers have been audited once and on a single tax report. In addition to them, 794 taxpayers have been audited more than once and 2,965 on more than one tax report (i.e. going backward and auditing past years). ${ }^{8}$ Overall, 21,231 taxpayers have been audited at least once during the sample period (audit rate 4\%). Clearly, multiple audits need to be considered with caution since the process of selection of taxpayers to be audited more than once and/or on more than one tax report is likely to be driven by non-observable and time-variant individual characteristics. This implies that

\footnotetext{
${ }^{8}$ No taxpayer in our sample has been audited more than once and on more than one tax report.
} 
estimates of audit effect would be affected by endogeneity. For this reason, we will focus our empirical analysis on audits concerning taxpayers audited once and on a single tax report ('single audits'). ${ }^{9}$

Table 1 shows that audits are concentrated in audit years 2011 and 2012: 61.8 percent of single audits are carried out during audit year 2012 and 27.6 percent during audit year 2011. The Table also shows clearly that audits are mainly concentrated on tax reports referring to four or five years before the audit year, which is just before evasion can no longer be prosecuted (after five years). For instance, considering audits carried out in 2012 (for which we can observe the entire period over which audit can be conducted, i.e. 2007-2011), 60.7 percent refer to the 2007 tax return and 30.2 percent to the 2008 tax return. This evidence suggests that, probably for organizational reasons, the $\mathrm{AE}$ tends to choose tax returns to be audited for a specific taxpayer on the basis of the year to which the tax report refers (i.e. mostly in the last two years in which tax returns can be audited). As regards the audit outcome, 9.6 percent of single audits end up with a null outcome, while the remaining 91.4 percent have a positive adjustment.

\section{[ Insert Table 1 Here ]}

One weakness of our data is that they cover only five years. This implies that taxpayers that have not been audited in our sample period could have been audited just before (e.g. in 2006). Hence, their behavior in the 2007-2011 period (especially in the first years of the period) may be influenced by audits that we are not able to observe. We will perform a robustness check in order to address this limitation.

A second limitation is that our data contain only observations relative to taxpayers present continuously in the AT for the whole 2007-2011 period, while

\footnotetext{
${ }^{9}$ In addition, given the limited temporal structure of our data, in the case of multiple audit the after-audit period would be necessarily higher on average than in the single audit case. This would hinder the interpretation of results because, as we will show, the dynamic audit effect is not linear.
} 
we do not observe taxpayers who entered or left the register because they either started or closed their business (e.g. due to decease or to closure caused by bankruptcy). On average these latter may react to an audit differently from the taxpayers in our sample. For instance, taxpayers close to bankruptcy may fail to react because of a cash flow shortage. Notice, however, that a time-variant sample composition would bias our analysis of the dynamic audits' effect. ${ }^{10}$

To analyze the effects of enforcement actions on subsequent reporting behavior, we consider as outcome the total personal income from self-employment and sole proprietorship as reported on taxpayers' tax returns. ${ }^{11}$ Taxes on this type of income are highly subject to evasion through misreporting or underreporting income. However, given that the magnitude of and the opportunity for evasion differ widely across types of income and deductions, we will use other outcomes in the robustness check Section. Specifically, we will check if our results hold when considering total before-tax income, taxable income, and net tax.

\section{Methods}

In the first part of this Section, we discuss the identification issues related to the estimation of the causal effect of real-world operational audits on subsequent tax compliance, and we describe how we address them. In the second part, we present and explain the equations to be estimated.

\section{A. Identification Issues}

When estimating the extent to which taxpayers adjust tax compliance behavior in response to an audit, we have to consider that audits (the treatment) are unlikely to

\footnotetext{
10 In view of this concern, DeBacker et al. (2015b), despite the availability of the entire population of tax filers, drop companies entering and exiting during the sample period to avoid this type of survivorship bias.

11 The Italian personal tax on income is computed by applying the increasing marginal rates of the progressive tax schedule to the taxable income, which is obtained by summing the different sources of income.
} 
be randomly assigned. In general, revenue agencies tend to audit subjects with a higher expected net return on the audit, maximizing the difference between its expected benefits and costs. This selection process can bias correlations of audits and taxpayers' tax compliance.

A first threat to our interpretation of the estimates is that the choice of the subjects to be audited may be based on time-invariant taxpayers' characteristics that are likely to be correlated with the outcome (reported income) but that we may not be able to observe. The panel structure of our data, with information on both pretreatment and post-treatment periods, enables us to circumvent this obstacle to identification. Our identification strategy relies on difference-in-difference comparison with non-audited taxpayers. We compare changes in outcome between taxpayers who were audited (the treated group) and taxpayers who were not audited (the control group). Moreover, considering that audited and non-audited taxpayers may differ in both observable and unobservable characteristics, we use a semiparametric ex-ante approach which restricts our control sample using Abadie et. al.'s (2004) nearest-neighbor matching algorithm. ${ }^{12}$ To match treated and control observations, for each taxpayer exposed to the treatment (i.e. audited) we identify the closest unaudited taxpayers based on gender, industry (classification based on 21 NACE groups), province (i.e. the geographical level at which the auditing policy is mainly established) and age deciles in 2007 , which is the beginning of our period of analysis. Given the large sample available, we have been able to perform exact matching on the above variables to select control taxpayers. As a robustness check, we will provide results obtained on the full sample of untreated taxpayers as well.

Overall, in our sample we have 17,472 treated taxpayers that were audited once and on one tax return in any of the 2007-2011 years. Considering that the matching

\footnotetext{
12 Estimation that combines ex-ante matching on observable characteristics with fixed-effects to account for time invariant unobserved factors produces more reliable estimates than matching alone (Smith and Todd, 2005).
} 
algorithm can match the same untreated taxpayer to more than one audited taxpayer, after unmatched observations are dropped, the control group is composed of 453,100 distinct taxpayers. Summary statistics for audited and matched nonaudited groups are reported in Table 2 for 2007. The means for the two groups are very close as regards age and gender distribution. Audited taxpayers are relatively less concentrated in Lombardy, the northern region, than in both the Centre and Southern regions. Audits are relatively more frequent in specific industries. Considering the most represented industries, audits occur more often in the wholesale and retail, transport, accommodation and food service activities and manufacturing sectors. The average pre-treatment income from professional and firm activity, the gross income, the taxable income and the average net tax paid is higher for audited taxpayers, suggesting that audits are actually not random. Specifically, it seems that the AE tends to audit more often taxpayers with higher levels of average reported income.

\section{[ Insert Table 2 Here ]}

A second threat for identification is that time-variant individual characteristics may affect treatment assignment. In particular, one may be concerned that audits are concentrated in years when reported income is relatively low or high. For instance, if the $\mathrm{AE}$ considers low reporting as a sign of evasion, an audit may be carried out when, for a given taxpayer, reported income is low relatively to her average reported income. This could invalidate our empirical design, and we would obtain upward biased estimates of the audit effect due to reverse causality. A similar concern is that taxpayers to be audited are selected by the AE looking at the value of other compliance-related variables such as gross income, taxable income or net tax, which may be time-variant.

The potential bias arising in this case is illustrated through an example in Figure 3. Let us consider a treated (audited, A) and a control (non-audited, NA) taxpayer. 
Assume that in period $\mathrm{t}-2$ and $\mathrm{t}-1$ both taxpayers report a constant and identical income. A temporary drop in taxpayer A reported income (unrelated to changes in her tax compliance) occurs at time $\mathrm{t}$ (in the absence of audit, at time $\mathrm{t}+1$ reported income would go back to its previous value), while income reported by taxpayer NA does not change. The tax authority considers the drop in reported income of taxpayer A as a signal of evasion and, accordingly, it audits her. Taxpayer A responds to the audit increasing her compliance by the amount AB. However, we would ascribe to the audit all the change in reported income from period t to period $\mathrm{t}+1$ (AC in Figure 3), even if part of this reported income increase (BC) would have occurred also in the absence of the audit.

\section{[ Insert Figure 3 Here ]}

To address this issue, first of all we consider that both the institutional setting, i.e. the five-year deadline for carrying out audits (see Section I), and the evidence in our data (see Section II, Table 1) suggest that the main criterion that the AE follows to select the specific tax return of a given taxpayer for an audit is its closeness to the expiration date. We therefore need to show that, conditional on this, the selection of taxpayers to be audited does not depend on compliance-related time-variant individual variables.

We provide evidence for this in Table 3, where we test whether specific levels of individual reported income, gross income, taxable income and net tax affect treatment assignment. Specifically, for taxpayers audited in 2012, for whom we observe a complete potential audit period (5 years), we estimate a linear fixed effect model for the probability of being audited. ${ }^{13}$ In addition to the above listed compliance-related variables, we include a Great Recession dummy in the specification because in our sample audits are concentrated in the pre-recession

\footnotetext{
13 In this test, we do not consider taxpayers audited in 2011 and before because we risk to classify as 'not audited' taxpayers audited on tax returns issued before 2007 .
} 
period, when reported income and the other considered variables were on average higher than in the following years.

Estimates confirm that taxpayers' probability of being audited is not correlated either with the year-specific level of their reported income or with other yearspecific time-variant variables (reported gross income, taxable income and net tax). Overall, therefore, given the Italian auditing policy, we are quite confident that there are no individual time-variant factors that affect the probability of being audited.

\section{[ Insert Table 3 Here ]}

\section{B. Estimating Equations}

To assess the average impact of audits on subsequent tax compliance, we estimate the relative change in reported income before and after the audit comparing audited taxpayers and the matched control sample of non-audited taxpayers by estimating the following equation:

$$
\text { (1) } Y_{i t j}=\beta_{1} \text { TREATED }_{i, t+1} \times \text { Post }_{t}+\alpha_{i}+\tau_{t}+\sigma_{j}+\gamma_{1} X_{i t j}+\varepsilon_{i t j}
$$

where $Y_{i t j}$ measures personal income as reported by taxpayer $i$ in industry $j$ in year $t$ and TREATED $D_{i, t+1}$ is a dummy equal to one for taxpayer $i$ that has been audited in year $\mathrm{t}+1$ (see Figure 2). The variable Post $t_{t}$ is a dummy equal to one for all periods from t onwards, since, for reasons illustrated in Section 3, we conjecture that the effect of an audit carried out in a given year starts from the tax return referring to the previous year. The effect of audits on tax compliance is captured by $\beta_{1}$, the coefficient for the interaction term between treated taxpayers and the post-audit period.

The terms $\alpha_{\mathrm{i}}, \tau_{\mathrm{t}}$ and $\sigma_{\mathrm{j}}$ are individual, year, and industry fixed effects, respectively. The individual fixed effects control for any observed or unobserved 
individual characteristics that are constant over time and that may affect the outcome. The year fixed effects control, in addition to macroeconomic fluctuations in general economic activity, for yearly changes in auditing guidelines established at central level. The inclusion of individual, year, and industry fixed effects should ensure that our comparison across treatment groups over time is not influenced by group-specific characteristics. $X$ is a vector of taxpayer characteristics. Finally, $\mathcal{E}$ is an error term.

The next step is estimating the dynamic effect of audits. More specifically, we want to assess if and how the audit's impact on reported income changes over time. For this purpose, we extend the primary specification given by equation (1) estimating the following equation:

(2) $Y_{i t j}=\sum_{t=1}^{5} \beta_{t}$ TREATED $D_{i, t+1} \times D_{-}$after $_{i t}+\alpha_{i}+\tau_{t}+\sigma_{j}+\gamma_{2} X_{i t j}+\varepsilon_{i t j}$

where D_after $i$ are a series of dummy variables, one for each year after the audit starts producing its effect, and the other variables retain the same meaning as in equation (1).

\section{Results}

Below, we provide a series of estimates of the impact of audits on reported income based on equation (1). We also test for different audit effects along the reported income distribution and we estimate the dynamic impact of audits based on equation (2). Thereafter, we present audit effects by audit outcome.

In all specifications, standard errors are clustered at taxpayer level to consider within-period correlations in the error term. We deflate all nominal values to 2011 euro. 


\section{A. Average Audit Effect}

Estimates of average audit effects based on equation (1) are reported in Table 4. In column 1, we show OLS results including only the "TREATED $\times$ Post" variable and year fixed effects; the specification shown in column 2 includes also industry and province fixed effects and controls for individual-level variables; columns 3 and 4 show results from different specifications of the difference-indifference fixed-effect model.

The coefficient $\beta_{1}$ of the "TREATED $\times$ Post" variable is positive and highly statistically significant in all columns. On comparing point estimates of OLS estimations, we find a higher coefficient when more controls are entered in the regression. More specifically, the increase in $\beta_{1}$ occurs when the provincial and the sectoral dummies are added. This is explained by the relatively greater concentration of audits in southern provinces of Sicily, where tax evasion is higher and the average reported income is considerably lower than in other regions. Data also indicate that on average reported income is lower in more frequently audited industries.

When we use the fixed effect estimator (columns 3 and 4), then controlling for time-invariant individual characteristics, the positive impact of audits is confirmed. However, the fixed effect estimate of $\beta_{1}$ is considerably lower than the OLS value: when controlling for individual time-variant characteristics (column 4), we find that annual reported income grows on average by almost 3.5 thousand euro after receiving an audit. In contrast, the OLS point estimate of $\beta_{1}$ in column 2 is around 7.6 thousand euro. This confirms that treatment assignment is indeed non-random and that OLS provides upward biased results. More specifically, the drop of $\beta_{1}$ suggests that taxpayers with higher average reported income are more likely to be audited. 
[ Insert Table 4 Here ]

The positive impact of audits on reported income is consistent with the prediction of the expected-utility maximization model of tax compliance that audited taxpayers increase future compliance when they revise upward their perceived probability of being audited.

To scrutinize further audit effect, we investigate whether it varies along the reported income distribution. To do so, we estimate equation (1) interacting the post-audit dummy with income deciles computed at the beginning of the period. The results are reported in Figure 4 (full estimation results are in Table A1 in the Appendix). They clearly show that the audit effect is higher at the lowest deciles. The $\beta_{1}$ coefficient is almost 18 thousand euro at the first decile, and it decreases monotonically along the reported income distribution, turning negative (minus 22 thousand euro) at the last decile. This result suggests that the average positive audit effect that we detected before is driven by low and middle reported-income taxpayers, while the effect is even negative at the highest decile. A similar result is found by Slemrod et al. (2001) in the Minnesota experiment, where a group of randomly selected taxpayers were informed by letter that the tax returns that they were about to file would be audited. They found that high-income taxpayers report less when they expect an audit. ${ }^{14}$ The main explanation provided by Slemrod et al. (2001) is that high-income taxpayers tend to believe that the final outcome of an audit depends on the initially reported income and that an audit will not necessarily discover all evasion. This belief is based on the assumption that high-income individuals are more likely to receive professional assistance with their tax affairs. We cannot test this hypothesis because reliable information about the presence and type of tax consultant is not available in our data.

\footnotetext{
14 Actually, our results are not directly comparable to those in Slemrod et. al. (2001) because in this latter study the treatment is the audit letter while in our case it is the audit itself.
} 


\section{[ Insert Figure 4 Here ]}

Another potential explanation for this result is that the marginal cost of increasing compliance differs along the income distribution. The marginal cost of reporting more income after the audit (the marginal effective tax rate) may be small or even zero for taxpayers whose taxable income is negative even after the post-audit correction, while is it much larger for high-income taxpayers. Indeed, we find that in the tenth decile the average marginal tax rate is $43 \%$, while up to the sixth decile it is not higher than $27 \%$ (see Table A2 in the Appendix). ${ }^{15}$

\section{B. Dynamic Audit Effect}

It is possible that the after-audit tax behavior changes over time because, as time since audit goes by, taxpayers are likely to revise their subjective audit probability based on more recent audit experience. More specifically, according to the target effect, individually perceived audit probability should decline with time and, in turn, tax compliance should progressively decrease. Through the dynamic analysis in this Section, we will test for the existence of different after-audit effects depending on the time elapsing since the occurrence of the audit. The dynamic effect of audits is represented by the vector $\beta_{\mathrm{t}}$ in equation (2), containing the coefficients of the interactions between the treatment dummy and dummy variables for the number of years elapsed since the audit

In the first year following an audit, taxpayers increase their reported income on average by around 2.7 thousand euro (see Table 5). In the following two years, the audit's effect is higher (around 5.5 thousand euro) while it seems to disappear from the fourth year onwards.

\footnotetext{
15 However, on the basis of the results in Kleven et al. (2011) showing a small effect of the marginal tax rate on tax evasion, we do not believe that our result can be explained mostly by this difference.
} 
[ Insert Table 5 Here ]

The lower first year effect is probably related to the temporal structure of the auditing mechanism (see Figure 2): year t audit may occur starting from July of tax year $\mathrm{t}-1$, when half of the tax year $\mathrm{t}-1$ has already passed. This means that behavior can be changed in response to the audit only in the second part of the fiscal year because, for the first part of the year, tax behavior with tax consequences has already been carried out. Moreover, a 'year t' audit could be carried on between January and July of year $t$, after tax year t-1 has already concluded. Although the Italian law allows for some ex-post upward correction of incomes resulting from accounting books, in this case the possibility to increase compliance is further reduced. For the subsequent tax years, instead, audited taxpayers have more possibility to adjust their behavior, although, after some more time has elapsed, the impact of the audit vanishes and tax compliance returns to the before-audit values after four years since audit. These results confirm our hypothesis that the first-year effect of an audit is limited. Moreover, given that for 60 percent of cases we observe only one year after audit, our average estimate is a lower bound.

\section{Audits' Effect by Audit's Outcome}

Our dataset is unique in allowing us to investigate audit impact by audit outcome. We distinguish between positive-assessment and null-outcome audits. The results on audit impact by type of outcome are set out in Table 6 . They show that in the case of null outcome the coefficient is negative but non-significant. This result is consistent with the predictions of the standard model of tax compliance. A nulloutcome audit may occur either if the taxpayer was actually compliant and AE acknowledges this or if the taxpayer evaded taxes and AE was not able to uncover evasion. In either case, the taxpayer has no reason to increase her subsequent income reports, and may actually report less if she thinks that, after a null-outcome 
audit, she is removed, for some time at least, from the set of taxpayers targeted by the AE. Moreover, in the case of cheating taxpayers, we expect a downward revision of the perceived probability that tax inspectors are successful in discovering evasion. On average, therefore, the effect on future reported income should be lower than in the positive-adjustment case. Indeed, our results show that when the outcome of the audit is a positive assessment of additional income, subsequent tax compliance increases significantly, on average by 4,110 euro. ${ }^{16}$

\section{[ Insert Table 6 Here ]}

Figure 5 shows the dynamic effect of audits separately by audit's outcome (full estimation results are in Table A3 in the Appendix). As it can be seen, in the case of audits with a positive assessment the effect is positive and significant up to the third year after audit, and the trend is similar to that emerged on average (see Table 5). In contrast, when considering null-outcome audits the effect is negative and significant in the first year, and turns non-significant afterwards. This result is consistent with a downward short-term revision of the probability to be targeted and audited, although a more behavioral explanation cannot be excluded. ${ }^{17}$

\section{[ Insert Figure 5 Here ]}

\section{Robustness}

In this Section we explore the robustness of our results to a number of potential threats to validity. First, we will provide evidence on the common trends assumption. Second, we will estimate equation (1) considering alternative measures of tax compliance as outcomes. Finally, we will replicate estimates on the full

\footnotetext{
16 In light of this result, we tested whether the lower audit effect for higher reported-income taxpayers that we found in subsection A could be driven by a higher concentration of taxpayers with high reported income among null-outcome audits. However, results of this analysis did not support this explanation.

17 A compliant taxpayer may feel that her time has been wasted during the audit and may evade more after a null-outcome audit in an attempt to "get back" at the tax authority (Andreoni et al., 1998).
} 
sample of untreated taxpayers (i.e. without ex-ante matching), winsorizing reported income at 99 percent and on the sample of taxpayers audited first in 2012.

\section{A. The Common Trend Assumption}

The estimation strategy that we adopt is based on the common trends assumption for untreated periods. We presume that in the absence of audits the treated and the untreated taxpayers would have shown a similar trend of tax compliance behavior. Figure 6 provides descriptive evidence for the parallel trends assumption by showing the average reported income over the period 2007-2011 for taxpayers audited first in 2012 and for those never audited in our sample period. ${ }^{18}$ Average income moves clearly in parallel in the two groups before the 2012 audit shows its effect, with the average level declining slightly in both groups. It is also evident that, as we expected, the trends diverge in the post-treatment period (i.e. in 2011).

\section{[ Insert Figure 6 Here ]}

To test more rigorously whether other possible unidentified differences between treated and control taxpayers may affect how audited taxpayers respond to audits, we present the results of a robustness check conducted to address this possibility by estimating a placebo version of equation (1) using data from the before-audit period of each audited taxpayer. More specifically, we compare relative changes in reported income between 2008 and 2009 (i.e. changes in the before-audit period between t-4 and t-3) for taxpayers audited first in 2012 with respect to the same change in reported income for untreated individuals. In this way, we are sure of excluding also potentially partially treated periods, like the $\mathrm{t}-2$ period.

The results in Table 7 show that the fake post-audit variable is negative and not statistically significant. The lack of a difference in this earlier period supports our

\footnotetext{
${ }^{18}$ We use the sub-sample of taxpayers audited first in 2012 to exclude effects of potential pre-2007 audits. Recall that taxpayers audited first in 2012 represent 60 percent of single audits.
} 
hypothesis that the relative change in reported income between audited and nonaudited taxpayers from the pre- to the post-audit period actually reflects the impact of the audit.

\section{[ Insert Table 7 Here ]}

\section{B. Different Outcomes and Estimates on Different Samples}

We check if our main results of Section IV hold for different outcome variables. First, we consider gross before-tax income. In addition to income from professional and firm activity, gross income includes other sources of income like those subject to house tax, rental tax or land value tax. Next, we test our main results using as the outcome taxable income (obtained by subtracting tax deductions like compulsory social security contributions from before-tax income) and the value of the net tax. The estimates in Table 8 (columns 1 to 3 ) confirm that, whatever the outcome considered, tax compliance increases in the post-audit period.

\section{[ Insert Table 8 Here ]}

As a further check of the robustness of our results, we replicate estimation without matching. Although ex-ante matching should help guarantee similarity between treated and control samples, we obtain almost identical results when we omit matching and use the full sample of untreated taxpayers (see Table 8, column 4). In order to check whether our results are not driven by outliers, in column 5 of Table 8 we show results obtained winsorizing reported income at 99 percent. Audit effect is still positive and significant, although lower than that found without winsorizing. ${ }^{19}$ Finally, given that we observe taxpayers only for the 2007-2011 period, we cannot exclude that they have been audited slightly before the beginning of our period of observation, for instance in 2006. If the audit effect persists over

\footnotetext{
19 Results (available upon request) are robust to different levels of winsorization.
} 
time, we risk classifying as non-treated some taxpayers for whom previous audit effects might be still be underway. ${ }^{20}$ Moreover, for taxpayers audited in 2012 we can observe the entire period over which they can be audited (i.e. 2007-2011). Then, as a robustness check, estimates in column 6 are obtained on the subsample of taxpayers audited first in 2012. The audit effect is still positive and significant, and the point estimate of $\beta_{1}$ (2,341 euro) is lower than when we use the whole sample of audited taxpayers. This difference is expected because in this case the post-audit period is just one year, and we have shown before that the audit's effect is not constant over time.

\section{A Back-of-the Envelope Calculation of the Net Tax-Revenue Effect of an Audit}

The net tax-revenue effect of an audit is the difference between its benefits and costs. Benefits are the sum of the additional tax yield (the direct effect) and the deterrence effect. They differ across audit outcomes, however. A null outcomeaudit does not generate any direct effect, while audits with a positive adjustment generate different direct effects depending on the specific audit outcome (no taxpayer's reaction, settlement, legal dispute). More specifically, audits concluded with no taxpayer's reaction yield an amount of additional taxes lower than the initial positive adjustment because in some cases the tax debt is impossible to collect. According to IMF (2016) estimates, the rate of effective collection of a euro assessed is 41 percent. ${ }^{21}$ The direct effect of audits concluded with a settlement yield an amount of additional taxes corresponding to the initial adjustment less the abatement. The direct effect of audits concluded with a legal dispute is lower than the initial positive adjustment for two reasons. First, it is possible that the dispute

\footnotetext{
20 As we have shown, the audit's effect tends to vanish after 4 years. Then, we are quite confident that for taxpayers audited first in 2012 there should still be no effect of potential pre-2007 audits.

21 The remaining 59\% of the tax debt is not collected for instance because the debtor is insolvent or because other provisions protecting taxpayer's assets are applicable. For more details see IMF (2016).
} 
is completely or partially lost by the AE. According to data provided by the AE, the probability of this event is 35 percent. Second, as said, the rate of effective collection is 41 percent. Thus, the direct effect is at least 26.7 percent $(0.41 \times 0.65)$ of the initial positive adjustment. Also the deterrence effect varies across audit outcomes. In terms of additional taxes, it can be computed by applying a hypothetical 27 percent average effective tax rate to the additional reported income for every audit outcome. ${ }^{22}$

The audit's benefits must be weighted against its costs. According to the OECD classification (OECD 2015), these latter can be related to: $i$ ) audit and other verification activities; ii) enforced debt collection and iii) dispute and appeals. To estimate these costs, we use confidential data provided by the AE. ${ }^{23}$ When the targets of audits are small businesses, every hour of activity has a cost of approximately 55 euro. Of these, 35 euro represent a direct cost (i.e. the hourly wage of a representative taxman) and 20 an indirect cost (i.e. the share of administrative costs attributable to the audit activity). The AE estimates that an audit on a small business requires 35 hours of work. As a result, the overall cost of an audit is 1925 euro.

For every euro spent on audits, the AE estimates a cost of 8 cents for debt collection and a cost of 23 cents for disputes and appeals. Accordingly, the debtcollection average cost is 154 euro $(0.08 \times 1925)$ and the dispute and appeals cost component is 443 euro $(0.23 \times 1925)$. These latter costs are not borne in the case of a settlement because the debt is immediately paid. In the case of no taxpayer's reaction, only the cost of debt collection is borne, while all three types of cost have

\footnotetext{
22 The additional reported income is equal to difference between reported income by audited and non-audited taxpayers differentiated by outcome type, estimated using the same estimator and specification as in Table 4 , column 4 . The differences amount to 4,553 euro in case of no taxpayer's reaction, 3662 euro in case of settlement, 5,216 in case of legal dispute and 1,210 euro in case of null outcome. We prefer to multiply these differences by the hypothetical average rate of 27 percent rather than using the net tax since the latter is likely influenced by heterogeneities in individual elements (tax deductions, allowances, etc.) which would alter the comparison.

23 OECD uses the same information for maintenance of the Tax Administration Database.
} 
to be paid when audits end up with a legal dispute. Table 9 shows the different components of the net tax-revenue of an audit. On (unweighted) average, the net tax-revenue of an audit is 3,806 euro. The average net tax-revenue weighted by shares of audits by outcome type is higher (5,856 euro) because the share of the most tax-revenue generating audits (those concluded with a settlement) is 54 percent, while the share of audits generating the lowest revenue (null-outcome audits) is 11 percent.

\section{[ Insert Table 9 Here ]}

On the one hand, these are conservative estimates because they ignore the spillover effects of tax audits, which can be important in the Italian setting (Galbiati and Zanella, 2012), as well as the effect of multiple audits. ${ }^{24}$ On the other hand, the net tax-revenue effect is different from the overall welfare effect. First, consumption of some private goods would have been financed by the (unpaid) taxes if audit had not taken place. Second, while most of the above-described administrative costs would cancel out since they correspond to wages paid to public employees, compliance has private costs whose magnitude is generally considered higher than the administrative costs of audits (Slemrod and Gilltzer, 2014).

\section{Conclusions}

During the last decades of the twentieth century, the theory of tax evasion was dominated by the Allingham-Sandmo model, where expected utility maximizing taxpayers decide the level of income to report considering the private costs and benefits of evasion. Subsequently, this model was criticized because, given the

\footnotetext{
24 Auditing activity presents scale economies: the average cost of audits is likely to decrease with the number of audits on the same taxpayer because during the subsequent audits some fixed costs, such as those related to acquiring information on time-invariant taxpayer characteristics, have already been borne by the tax authority. Scale economies arise also when more tax returns are checked upon the same audit due to the fixed cost related to opening an audit. Thus, the average audit cost and the average audit cost per tax return are lower in the case of multiple audits.
} 
actual levels of sanctions and the frequency of audits, it predicts evasion much higher than that observed. This induced many scholars to look for alternative explanations of tax evasion more related to "intrinsic motivations".

More recently, some studies have highlighted that when detection probability is correctly computed taking the presence of third-party information into account, taxpayers' behavior is more in line with the Allingham-Sandmo model (Kleven et al., 2011). The explanation of high tax compliance may also depend on taxpayers' mistakes in estimating detection probability and penalties (Chetty, 2009). Overall, the "cynical" view of the taxpayer maximizing her expected gain from the tax evasion lottery has thus regained attention and credit in this literature.

Our paper contributes to this stream of research by studying the impact of audits on subsequent tax compliance for a large panel of Italian taxpayers. It is the first study to use real-world operational audits on individual taxpayers. Both our econometric strategy and the Italian institutional setting allow us to address potential endogeneity related to non-random selection of taxpayers to be audited.

In line with the theoretical predictions of the expected utility model of tax compliance, we find a positive average effect of audits on reported income of approximately 8.2 percent $(3,472 / 42,280$ euro). However, when the taxpayer is found compliant we find a negative effect that vanishes after one year. Using data on audit's cost and our results, we estimate a net tax-revenue effect of audits ranging from 3.8 thousand euro (unweighted average) to around 5.8 thousand euro (when weighted by audit outcome).

The issue of the external validity of our results naturally arises. Citizenries differ among themselves with respect to the magnitude and nature of noncompliance, to the norms that matter, and to the institutional environment (Slemrod, 2016). Italy is known to be a country with low tax morale, where tax amnesties are frequent and institutions (including the tax administration) are relatively less efficient than those operating in other developed countries. These elements may reduce the impact of 
audits, for example because a lower social stigma is attached to non-compliant taxpayers or because the expected penalty of evasion is low if the tax authority is less efficient or the law offers more loopholes and tax amnesties. Then, our estimates of audit's effect may be considered a lower bound for countries, such as the US or Nordic European Countries, where tax morale is higher and tax norms and institutions are more efficient than in Italy. ${ }^{25}$ A more efficient tax authority may have lower audit and debt collection costs as well. Overall, then, also the estimated net tax-revenues from audit activity would be even higher in these countries.

Our analysis can be sharpened on some dimensions. First, with the current database, we were not able to estimate the private compliance costs borne by taxpayers both during and after audits, and to provide a meaningful analysis of the welfare impact of audits. Although some components of private costs are transfers irrelevant to welfare (e.g. payments to consultants and lawyers), other components imply a net loss (e.g. the opportunity cost of time spent on avoiding and responding to audits). Additional data on the type (i.e. computer-based or inspection-based; involving investigation of accounting books and crosschecking or not, etc.) and the length of each audit, coupled with an estimate of the opportunity cost of time along the lines provided by the Doing Business Database of the World Bank, would allow the estimation of the private compliance costs.

Second, in this study we ignored audits regarding taxpayers audited more than once and on more than one tax return (i.e. multiple audits). A longer panel and more information on the process driving the selection of taxpayers for multiple audits would allow us to provide some evidence on how compliance responds to different intensity of treatment. When a second audit is carried out a few years after the first,

\footnotetext{
25 Clearly, the impact of an audit depends also on the propensity to evade. However, in the US the propensity to evade the self-employment tax and the non-farm proprietor income tax has been estimated at $52 \%$ and $57 \%$, respectively (Slemrod, 2007); these values are very close to the propensity to evade taxes on income from self-employment and sole proprietorships estimated for Italy $(59.4 \%$, see the official report on Italian evasion by the Ministry of Finance, available at http://www.mef.gov.it/inevidenza/documenti/Relazione_evasione_fiscale_e_contributiva_0926_ore1300_xversione_defin itivax-29_settembre_2016.pdf, Table 3.E.2, p. 38)
} 
we expect a larger effect of later audits because these latter could induce taxpayers to reinforce their belief of being targeted by the tax authority, leading to an additional upward revision of their subjective audit probability and, accordingly, to a further increase in reported post-audit income. A similar mechanism is likely in place in the case of taxpayers audited on more than one tax return. The analysis of the effect of multiple audits would be relevant for the estimate of the tax-revenues effect of audits as well.

Third, in this paper we have shown that the impact of audits tends to decrease along the reported income distribution, which suggests that enforcement policies may reduce reported income dispersion. In view of this result, looking at the distributional implications of enforcement policies is another potential extension of our study and, more in general, of this stream of research (Slemrod, 2016). Obviously, this would require the identification of the reasons why high reportedincome taxpayers respond less to audits.

Finally, looking at audit's effect on the different income components (i.e. reported costs separately from reported revenues) would be interesting to test whether costs move in the same direction as revenues in response to an enforcement initiative, thus reducing the response of reported taxable income. In this respect, recent evidence has shown that when firms are notified about discrepancies between their declared revenues and revenues reports from third-party sources, they increase reported revenues but offset almost the entire adjustment with increases in reported costs, resulting in only minor increases in total tax collection (Carrillo et al., 2014).

\section{REFERENCES}

Abadie, Alberto, David Drukker, Jane L. Herr, and Guido W. Imbens. 2004. "Implementing Matching Estimators for Average Treatment Effects in Stata." 
The Stata Journal 4(3): 290-311.

Advani, Arun, William Elming, and Jonathan Shaw. 2015. "How Long-lasting are the Effects of Audits." Discussion paper 015-15, Tax Administration Research Centre.

Allingham, Michael G., and Agnar Sandmo. 1972. "Income Tax Evasion: A Theoretical Analysis" Journal of Public Economics 1, issue 3-4, p. 323-338.

Andreoni, James, Brian Erard, and Jonathan Feinstein. 1998. "Tax compliance.” Journal of economic literature 36(2): 818-860.

Best, Michael C. 2014. 'The Role of Firms in Workers' Earnings Responses to Taxes: Evidence from Pakistan." mimeo

Cabral, Ana Cinta G., Christos Kotsogiannis, and Gareth Myles. 2014. "Selfemployment Underreporting in Great Britain: Who and How Much?." Tax Administration Research Centre. University of Exeter Discussion Paper no.01014.

Carrillo, Paul, Pomeranz, Dina, and Monica Singhal. 2014. "Dodging the Taxman: Firm Misreporting and Limits to Tax Enforcement.” Harvard Business School Working Paper n. 15-026. Forthcoming in American Economic Journal: Applied Economics.

Chetty, Raj. 2009. "Is the Taxable Income Elasticity Sufficient to Calculate Deadweight Loss? The Implications of Evasion and Avoidance." American Economic Journal: Economic Policy 1.2: 31-52.

DeBacker, Jason, Bradley T. Heim, Anh Tran, and Alexander Yuskavage, 2015a. "Once Bitten, Twice Shy? The Lasting Impact of IRS Audits on Individual Tax Reporting", mimeo.

DeBacker, Jason, Bradley T. Heim, Anh Tran, and Alexander Yuskavage, 2015b. "Legal Enforcement and Corporate Behavior: An Analysis of Tax Aggressiveness after an Audit.” The Journal of Law and Economics, 58(2): 291324. 
Dwenger, Nadja, Henrik Kleven, Imran Rasul, and Johannes Rincke. 2016. "Extrinsic and Intrinsic Motivations for Tax Compliance: Evidence from a Field Experiment in Germany." American Economic Journal: Economic Policy 8(3): 203-32

Galbiati, Roberto, and Giulio Zanella. 2012. "The Tax Evasion Social Multiplier: Evidence from Italy.” Journal of Public Economics 96 (5): 485-494.

Gemmell, Norman, and Marisa Ratto. 2012. "Behavioral Responses to Taxpayer Audits: Evidence from Random Taxpayer Inquiries.” National Tax Journal 65(1): $35-58$.

IMF. 2016. "Italy. Technical Assistance Report-Enhancing Governance and Effectiveness of the Fiscal Agencies.” IMF Country Report N.16/241.

Italian Ministry of Economy and Finance. 2016. "Relazione sull'economia non osservata e sull'evasione fiscale e contributiva", available at http://www.mef.gov.it/inevidenza/documenti/Relazione_evasione_fiscale_e_co ntributiva_0926_ore1300_xversione_definitivax-29_settembre_2016.pdf

Kleven, Henrik Jacobsen. 2014. "How can Scandinavians Tax So Much?." The Journal of Economic Perspectives 28(4): 77-98.

Kleven, Henrik J., Martin B. Knudsen, Claus T. Kreiner, Søren Pedersen, and Emmanuel Saez (2011). 'Unwilling or Unable to Cheat? Evidence From a Tax Audit Experiment in Denmark'. Econometrica, 79(3): 651-692.

Luttmer, Erzo F.P., and Monica Singhal. 2014. "Tax Morale." The Journal of Economic Perspectives 28(4): 149-168.

Oecd. 2015. "Tax Administration 2015. Comparative Information about Oecd and Other Advanced and Emerging Economies." Oecd Publishing, Paris.

Paulus, Alari. 2015. "Tax Evasion and Measurement Error: An Econometric Analysis of Survey Data Linked with Tax Records." Institute for Social and Economic Research, University of Essex Working Paper No. 2015-10.

Pissarides, Christopher A., and Guglielmo Weber. 1989. “An Expenditure-Based 
Estimate of Britain's Black Economy." Journal of Public Economics 39(1): 1732.

Santoro, Alessandro, and Carlo V. Fiorio. 2011. "Taxpayer Behavior when Audit Rules are Known: Evidence from Italy." Public Finance Review 39(1): 103-123 Slemrod, Joel. 2004. "The Economics of Corporate Tax Selfishness." National Tax Journal 57(4):877-899.

Slemrod, Joel. 2016. "Tax Compliance and Enforcement: New Research and its Policy Implications.” Ross School of Business Working Paper 1302. University of Michigan.

Slemrod, Joel, Marsha Blumenthal, and Charles Christian. 2001. "Taxpayers Response to an Increased Probability of Audit: Evidence from a Controlled Experiment in Minnesota.” Journal of Public Economics 79:455-483.

Slemrod, Joel, and Christian Gillitzer. 2014. "Editor's Choice Insights from a TaxSystems Perspective." CESifo Economic Studies 60(1): 1-31.

Smith, Jeffrey A., and Petra E. Todd. 2005. "Does Matching Overcome LaLonde's Critique of Nonexperimental Estimators?” Journal of Econometrics 125(1-2): 305-353. 
TABLE 1-DISTRIBUTION OF AUDIT BY AUDIT YEAR AND BY INSPECTED TAX RETURN

\begin{tabular}{lcccccc}
\hline \hline & \multicolumn{6}{c}{ Tax return } \\
Audit year & 2007 & 2008 & 2009 & 2010 & 2011 & Total \\
\hline 2008 & 64 & - & - & - & - & 64 \\
2009 & 488 & 15 & - & - & - & 503 \\
2010 & 1,116 & 179 & 9 & - & - & 1,304 \\
2011 & 2,576 & 2,101 & 119 & 15 & - & 4,811 \\
2012 & 6,547 & 3,256 & 759 & 212 & 16 & 10,790 \\
& & & & & & \\
Total & 10,791 & 5,551 & 887 & 227 & 16 & 17,472 \\
\hline
\end{tabular}


TABLE 2-BASELINE TAXPAYER CHARACTERISTICS

\begin{tabular}{|c|c|c|c|c|}
\hline & \multicolumn{2}{|c|}{ Audited } & \multicolumn{2}{|c|}{ Non audited (matched) } \\
\hline & Mean & Std dev & Mean & Std dev \\
\hline \multicolumn{5}{|l|}{ Outcomes } \\
\hline Personal income from professional and firm activity & $42,279.9$ & $98,457.8$ & $37,213.6$ & $79,612.1$ \\
\hline Gross income & $42,233.2$ & $98,605.0$ & $36,963.4$ & $79,693.1$ \\
\hline Taxable income & $46,969.5$ & $125,326.8$ & $38,108.5$ & $101,183.2$ \\
\hline Net tax & $14,697.8$ & $53,119.7$ & $10,962.9$ & $42,787.0$ \\
\hline Age & 47.4 & 11.6 & 46.2 & 11.3 \\
\hline Male & 0.79 & & 0.80 & \\
\hline \multicolumn{5}{|l|}{ Industry share } \\
\hline Agriculture, forestry and fishing & 3.3 & & 6.1 & \\
\hline Mining and quarrying & 0.0 & & 0.0 & \\
\hline Manufacturing & 6.6 & & 6.3 & \\
\hline Water supply; sewerage; waste manag. and remediation activities & 0.1 & & 0.0 & \\
\hline Construction & 11.9 & & 13.8 & \\
\hline Wholesale and retail; repair of motor vehicles and motorcycles & 29.4 & & 27.7 & \\
\hline Transporting and storage & 3.9 & & 2.5 & \\
\hline Accommodation and food service activities & 7.7 & & 3.9 & \\
\hline Information and communication & 1.2 & & 1.3 & \\
\hline Financial and insurance activities & 1.7 & & 0.9 & \\
\hline Real estate activities & 1.2 & & 0.7 & \\
\hline Professional, scientific and technical activities & 21.0 & & 26.6 & \\
\hline Administrative and support service activities & 3.0 & & 2.1 & \\
\hline Education & 0.3 & & 0.1 & \\
\hline Human health and social work activities & 3.5 & & 3.8 & \\
\hline Arts, entertainment and recreation & 2.1 & & 1.4 & \\
\hline Other services activities & 3.1 & & 2.9 & \\
\hline \multicolumn{5}{|l|}{ Region } \\
\hline Lombardy (North) & 32.2 & & 52.5 & \\
\hline Lazio (Centre) & 37.4 & & 27.0 & \\
\hline Sicily (South) & 30.4 & & 20.5 & \\
\hline $\mathrm{Nr}$ taxpayers & 17,472 & & 453,100 & \\
\hline
\end{tabular}

Notes: The sample of audited taxpayers is restricted to taxpayers audited once and on one tax return in any of the 2007-2011 years. The (matched) sample of non-audited taxpayers is restricted to non-audited taxpayers matched to the sample of taxpayers audited once and on one tax return. Gross income includes other sources of income like those subject to house tax, rental tax or land value tax in addition to income from professional and firm activity. Taxable income is obtained by subtracting tax deductions like compulsory social security contributions from before-tax income. 
TABLE 3-SINGLE TAXPAYER AUDIT PROBABILITY

\begin{tabular}{lcccc}
\hline \hline & & & \\
& $(1)$ & $(2)$ & $(3)$ & $(4)$ \\
\hline Reported income & $1.48 \mathrm{E}-08$ & & & \\
& {$[2.62 \mathrm{E}-08]$} & & & \\
Reported gross income & & $-4.08 \mathrm{E}-09$ & & \\
& & {$[2.88 \mathrm{E}-08]$} & & $-3.81 \mathrm{E}-08$ \\
Reported taxable income & & & {$[2.92 \mathrm{E}-08]$} & \\
& & & & $-6.95 \mathrm{E}-08$ \\
Net tax & & & & {$[6.56 \mathrm{E}-08]$} \\
& & & & \\
Constant & 0.454 & 0.454 & 0.456 & 0.455 \\
& {$[0.002]$} & {$[0.002]$} & {$[0.002]$} & {$[0.002]$} \\
& & & & \\
Observations & 53,950 & 53,950 & 53,950 & 53,950 \\
R-squared & 0.269 & 0.269 & 0.269 & 0.269 \\
Number of id & 10,790 & 10,790 & 10,790 & 10,790 \\
\hline
\end{tabular}

Notes : Linear fixed effect model for the probability of being audited on a specific-year tax return. The estimation sample is restricted to taxpayers audited in 2012. The dependent variable takes the value of 1 if the individual observation refers to the tax year whose tax return has been audited. Robust standard errors are in parentheses, clustered at the taxpayer level. All specifications include a control for the post-Great Recession period. 


\begin{tabular}{lcccc}
\hline \hline & \multicolumn{4}{c}{ Reported income } \\
& $(1)$ & $(2)$ & $(3)$ & $(4)$ \\
& OLS w/o control & OLS with controls & FE w/o control & FE with control \\
\hline Audit effect & $4,789.22$ & $7,591.909$ & $3,079.46$ & $3,471.898$ \\
& {$[580.166]$} & {$[556.275]$} & {$[372.334]$} & {$[371.373]$} \\
& & & & \\
Constant & $37,401.05$ & $-49,561.435$ & $37,401.28$ & $-44,486.045$ \\
& {$[117.195]$} & {$[1,265.478]$} & {$[53.583]$} & {$[2,502.199]$} \\
& & & & \\
Individual controls & NO & YES & NO & YES \\
Year FE & YES & YES & YES & YES \\
Province FE & NO & YES & NO & YES \\
Industry FE & NO & YES & NO & YES \\
Individual FE & NO & & YES & YES \\
& $2,352,860$ & $2,352,860$ & $2,352,860$ & $2,352,860$ \\
Observations & 0.003 & 0.066 & 0.013 & 0.017 \\
R-squared & & & 470,572 & 470,572 \\
Number of id & & & & \\
\hline
\end{tabular}

Notes: Columns 1 and 2 report OLS estimates. Columns 3 and 4 report fixed-effect estimates. Robust standard errors are in parentheses, clustered at the taxpayer level. Individual controls are gender, age and squared age. 
TABLE 5-DYNAMIC AUDIT EFFECT

\begin{tabular}{lc}
\hline \hline & FE \\
\hline I year effect & $2,734.687$ \\
& {$[382.309]$} \\
II year effect & $5,687.376$ \\
& {$[580.172]$} \\
III year effect & $5,589.778$ \\
& {$[1,505.463]$} \\
IV year effect & $3,501.721$ \\
& {$[2,430.974]$} \\
V year effect & $4,716.830$ \\
& {$[4,440.872]$}
\end{tabular}

Constant

$-44,321.976$

[2,504.742]

Individual controls

YES

Year FE

YES

Province FE

YES

Industry FE

YES

Individual FE

YES

Observations

$2,352,860$

Number of id

470,572

R-squared

0.017

Notes: Robust standard errors are in parentheses, clustered at the taxpayer level. Individual controls are gender, age and squared age. 


\section{TABLE 6-AUDIT EFFECT BY AUDIT OUTCOME}

\begin{tabular}{lc}
\hline \hline & FE \\
VARIABLES & $(1)$ \\
\hline Audit effect (null audit) & $-1,211.389$ \\
& {$[893.921]$} \\
Audit effect (positive assessment audit) & $4,110.734$ \\
& {$[386.211]$} \\
& \\
Constant & $-64,397.281$ \\
& {$[2,347.520]$} \\
& \\
Individual controls & YES \\
Year FE & YES \\
Province FE & YES \\
Industry FE & YES \\
Individual FE & YES \\
& \\
Observations & $2,352,860$ \\
R-squared & 470,572 \\
Number of id & 0.013 \\
\hline
\end{tabular}

Notes : See notes to Table 5 
TABLE 7-PLACEBO REGRESSION

\begin{tabular}{lc}
\hline \hline VARIABLES & $\begin{array}{c}\text { Reported income } \\
(2008-2009 \text { diff })\end{array}$ \\
\hline Audit effect (placebo) & -553.025 \\
& {$[748.693]$} \\
Constant & $17,131.813$ \\
& {$[7,054.173]$} \\
Individual controls & YES \\
Year FE & YES \\
Province FE & YES \\
Industry FE & YES \\
Individual FE & YES \\
& \\
Observations & 927,780 \\
Number of id & 463,890 \\
R-squared & 0.007 \\
\hline Notes : Robust standard errors are in parentheses, clustered at the
\end{tabular}

Notes : Robust standard errors are in parentheses, clustered at the taxpayer level. The audited taxpayer sample is restricted to taxpayers audited in 2012. The specification is the same as in column 4 of Table 4 with the exception of the placebo audit effect. 
TABLE 8-ALTERNATIVE OUTCOME VARIABLES AND SAMPLES

\begin{tabular}{|c|c|c|c|c|c|c|}
\hline & Reported gross & Taxable income & Net tax & & Reported income & \\
\hline & (1) & $(2)$ & (3) & $\begin{array}{c}\text { No matching } \\
\text { (4) }\end{array}$ & $\begin{array}{c}99 \% \text { winsorizing } \\
(5)\end{array}$ & $\begin{array}{c}\text { Audit in } 2012 \\
\text { (6) }\end{array}$ \\
\hline \multirow[t]{2}{*}{ Audit effect } & $2,400.367$ & $1,717.877$ & 615.698 & 3284.298 & $2,556.011$ & $2,341.884$ \\
\hline & [346.849] & [341.199] & {$[144.340]$} & [370.4977] & [203.394] & [514.203] \\
\hline \multirow[t]{2}{*}{ Constant } & $-74,477.816$ & $-44,788.389$ & $-19,666.293$ & -44699.69 & $-23,587.802$ & $-44,475.757$ \\
\hline & {$[2,169.785]$} & {$[2,482.610]$} & {$[1,052.261]$} & [2277.231] & {$[1,305.756]$} & {$[2,515.674]$} \\
\hline Individual controls & YES & YES & YES & YES & YES & YES \\
\hline Year FE & YES & YES & YES & YES & YES & YES \\
\hline Province FE & YES & YES & YES & YES & YES & YES \\
\hline Industry FE & YES & YES & YES & YES & YES & YES \\
\hline Individual FE & YES & YES & YES & YES & YES & YES \\
\hline Observations & $2,352,860$ & $2,352,860$ & $2,352,860$ & $2,623,905$ & $2,352,860$ & $2,319,450$ \\
\hline R-squared & 0.006 & 0.003 & 0.002 & 0.001 & 0.049 & 0.017 \\
\hline Number of id & 470,572 & 470,572 & 470,572 & 524,781 & 470,572 & 463,890 \\
\hline
\end{tabular}

Notes : Robust standard errors are in parentheses, clustered at the taxpayer level. Estimates in column 4 are obtained considering the whole sample of non-audited taxpayers. Estimates in column 5 are obtained winsorizing the dependent variable at 99\%. In column 6 the audited taxpayer sample is restricted to taxpayers audited in 2012. Individual controls are gender, age and squared age. 
TABLE 9-AUDIT NET TAX REVENUES

\begin{tabular}{|c|c|c|c|c|c|c|}
\hline & & Null outcome & No reaction & Settlement & Legal dispute & Average \\
\hline $\begin{array}{l}\text { Assessment } \\
\text { (taxes) }\end{array}$ & & 0 & 11879 & 9268 & 23501 & 11162 \\
\hline \multirow[t]{3}{*}{ BENEFITS (1) } & Tax yield (Direct effect) (2) & 0 & $4870^{*}$ & 9268 & $6263 * *$ & 5100 \\
\hline & Deterrence $\operatorname{effect}^{\circ}(3)$ & -327 & 1202 & 989 & 1408 & 818 \\
\hline & Total $(1)=(2)+(3)$ & -327 & 6073 & 10256 & 7671 & 5918 \\
\hline \multirow[t]{4}{*}{ COSTS (4) } & Audit $^{+}(5)$ & 1925 & 1925 & 1925 & 1925 & 1925 \\
\hline & Debt collection $^{++}(6)$ & 0 & 154 & 0 & 154 & 77 \\
\hline & Dispute and appeals $^{+++}(7)$ & 0 & 0 & 0 & 443 & 111 \\
\hline & $\operatorname{Total}(4)=(5)+(6)+(7)$ & 1925 & 2079 & 1925 & 2522 & 2113 \\
\hline \multicolumn{2}{|c|}{$\begin{array}{l}\text { NET TAX REVENUE EFFECT } \\
(8)=(1)-(4)\end{array}$} & -2252 & 3994 & 8331 & 5149 & 3806 \\
\hline \multicolumn{2}{|c|}{ Share of total revenues (9) } & 0.11 & 0.19 & 0.54 & 0.16 & \\
\hline \multicolumn{2}{|c|}{ WEIGHTED NET EFFECT $=(9) \times(8)$} & -244 & 752 & 4530 & 817 & 5856 \\
\hline
\end{tabular}

Notes: $* 0.41$ of positive assessment; $* * 0.41 \mathrm{x} 0.65$ of positive assessment; ${ }^{\circ} 0.27 \mathrm{x}$ audit effect (see footnote 20 ); + the values correspond to 55 (hourly cost of audits) x 35 (nr of hours required); ++ the debt collection cost (154=1925x0.08) amounts to 0.08 euro for each euro spent on audit; +++ the dispute and appeals cost $(443=1925 \times 0.23)$ amounts to 0.23 for each euro spent on audit. 
TABLE A1-AUDIT EFFECT BY REPORTED INCOME DECILE

\begin{tabular}{|c|c|}
\hline & FE \\
\hline \multicolumn{2}{|l|}{ Audit effect } \\
\hline \multirow[t]{2}{*}{ I decile } & $17,784.922$ \\
\hline & {$[1,039.030]$} \\
\hline \multirow[t]{2}{*}{ II decile } & $9,881.031$ \\
\hline & [386.474] \\
\hline \multirow[t]{2}{*}{ III decile } & $7,111.581$ \\
\hline & [357.342] \\
\hline \multirow[t]{2}{*}{ IV decile } & $6,301.752$ \\
\hline & [476.652] \\
\hline \multirow[t]{2}{*}{ V decile } & $5,805.142$ \\
\hline & [457.149] \\
\hline \multirow[t]{2}{*}{ VI decile } & $4,699.704$ \\
\hline & [507.864] \\
\hline \multirow[t]{2}{*}{ VII decile } & $4,492.040$ \\
\hline & {$[600.860]$} \\
\hline \multirow[t]{2}{*}{ VIII decile } & $2,788.115$ \\
\hline & [648.011] \\
\hline \multirow[t]{2}{*}{ IX decile } & 33.260 \\
\hline & [779.674] \\
\hline \multirow[t]{2}{*}{$\mathrm{X}$ decile } & $-22,054.429$ \\
\hline & {$[2,587.976]$} \\
\hline \multirow[t]{2}{*}{ Constant } & $-43,094.963$ \\
\hline & {$[2,491.334]$} \\
\hline Individual controls & YES \\
\hline Year FE & YES \\
\hline Province FE & YES \\
\hline Industry FE & YES \\
\hline Individual FE & YES \\
\hline Observations & $2,352,860$ \\
\hline Number of id & 470,572 \\
\hline R-squared & 0.018 \\
\hline
\end{tabular}

Notes: See notes to Table 5 
TABLE A2-DESCRIPTIVE STATISTICS AND MARGINAL TAX RATE BY DECILES OF REPORTED INCOME

\begin{tabular}{lcccccc}
\hline \hline $\begin{array}{l}\text { Reported income } \\
\text { (decile) }\end{array}$ & Nr.obs & \multicolumn{2}{c}{ Reported income } & Min & Marginal \\
tax rate
\end{tabular}

Notes: The source for the marginal tax rate is www.finanze.it. 
TABLE A3-DYNAMIC AUDIT EFFECT BY AUDIT OUTCOME

\begin{tabular}{lc}
\hline \hline & FE \\
\hline Panel A: Null outcome & \\
I year effect & $-2,502.365$ \\
& {$[1,028.397]$} \\
II year effect & 880.297 \\
& {$[1,693.745]$} \\
III year effect & 401.753 \\
& {$[2,541.762]$} \\
IV year effect & -245.199 \\
& {$[4,550.488]$} \\
V year effect & $3,304.377$ \\
& {$[3,642.220]$} \\
Panel B: Positive assessment & \\
I year effect & $3,362.918$ \\
& {$[409.573]$} \\
II year effect & $6,139.324$ \\
& {$[613.739]$} \\
III year effect & $6,135.093$ \\
& {$[1,662.664]$} \\
IV year effect & $3,875.583$ \\
& {$[2,722.214]$} \\
V year effect & $5,107.016$ \\
& {$[4,612.492]$} \\
Constant & $-44,289.728$ \\
& {$[2,504.529]$} \\
Individual controls & \\
Year FE & YES \\
Province FE & YES \\
Industry FE & YES \\
Individual FE & YES \\
Observations & YES \\
Number of id & \\
R-squared & $2,352,860$ \\
Noes: See & 470,572 \\
& 0.017 \\
\hline
\end{tabular}

Notes: See notes to Table 5 


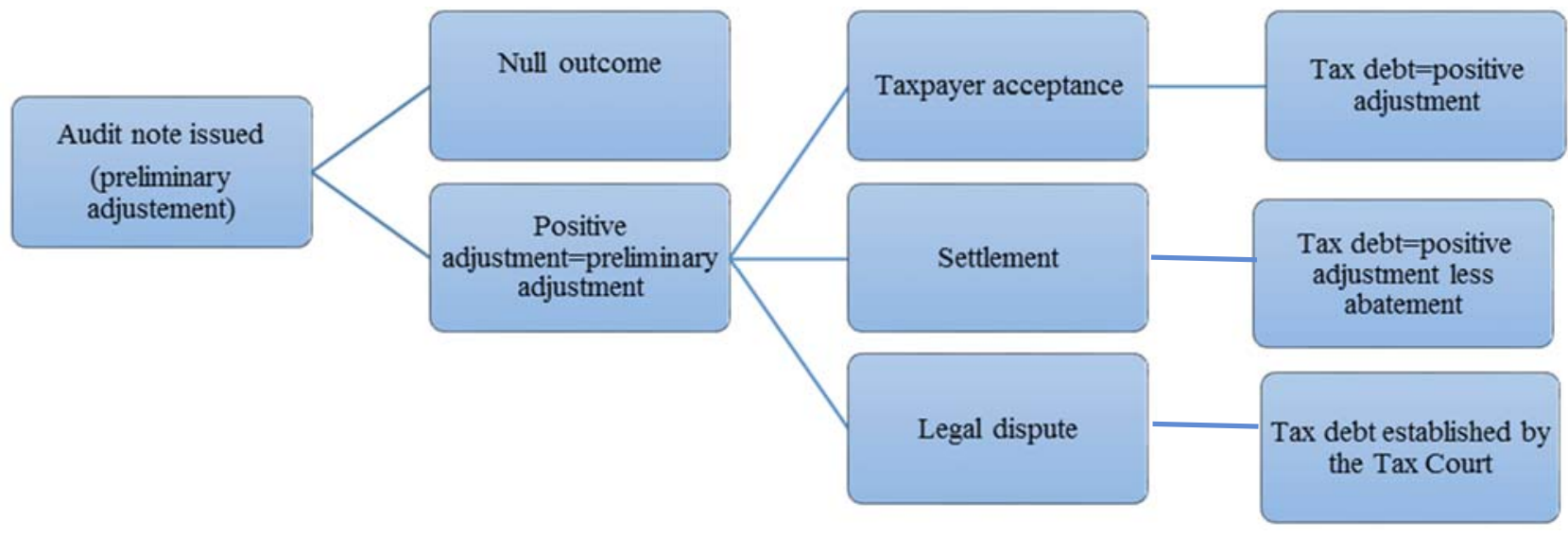

FIGURE 1-AUDIT'S OUTCOMES

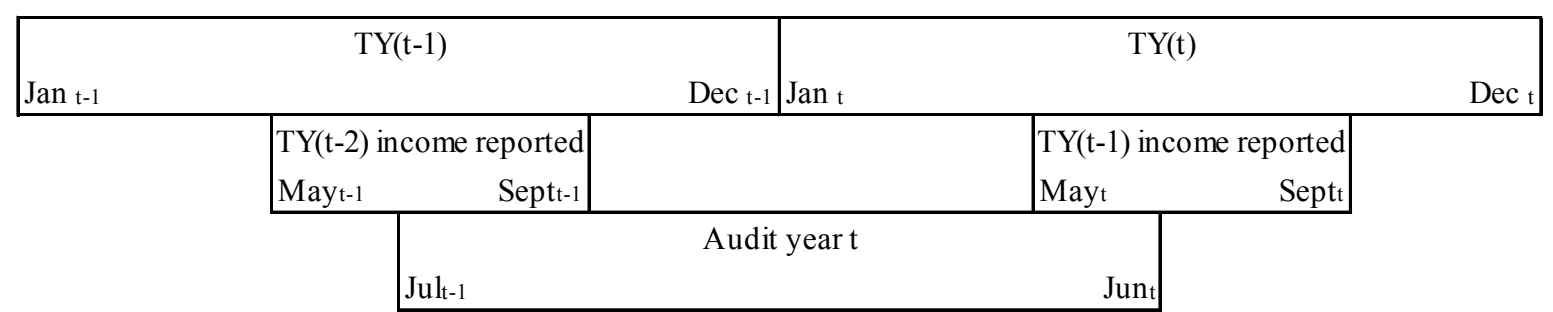

FIGURE 2- REPORTING AND AUDITING TIME STRUCTURE

Notes: TY: Tax year 


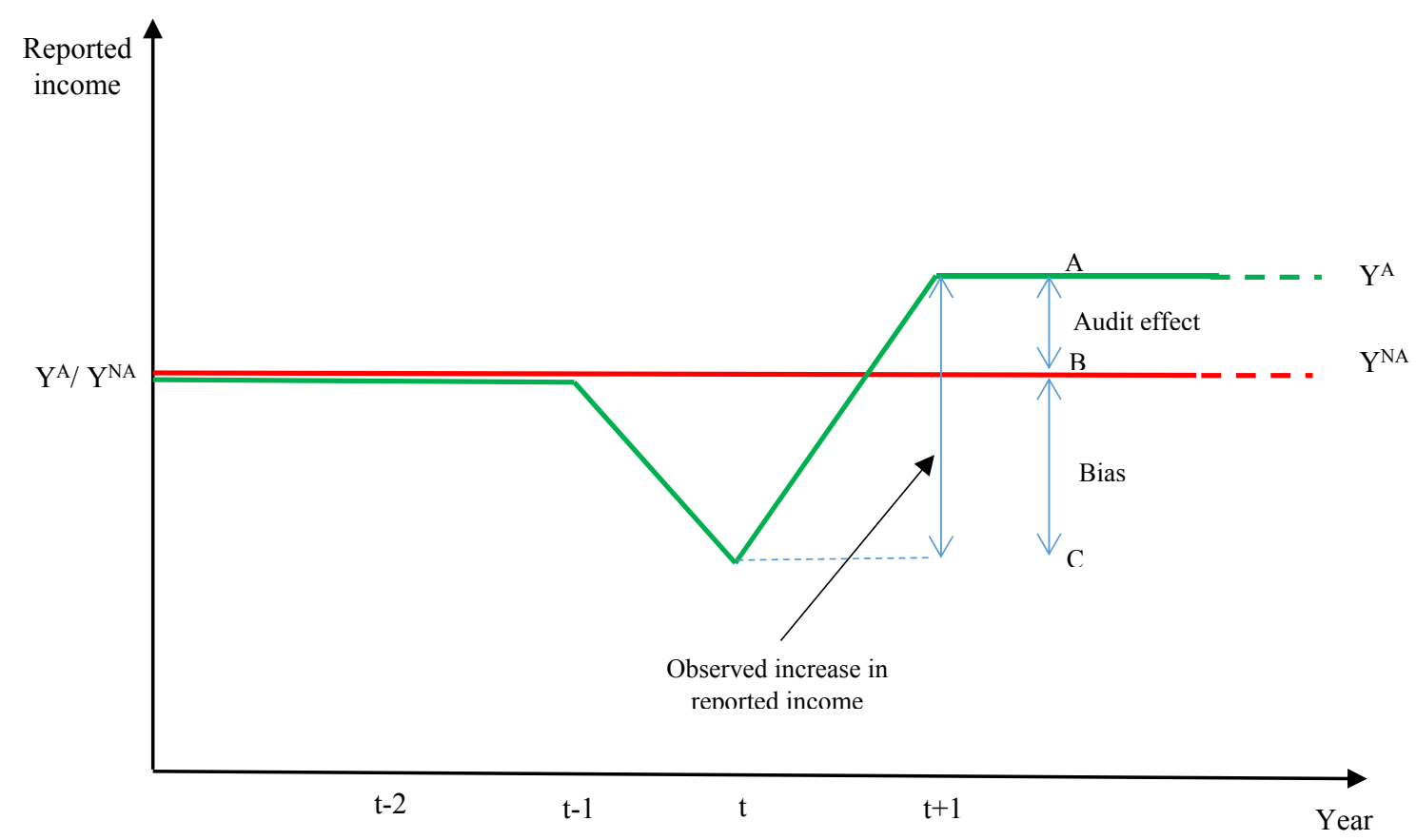

FIGURE 3-ESTIMATION BIAS IN PRESENCE OF TIME-VARIANT FACTORS AFFECTING TREATMENT ASSIGNMENT

Notes: $\mathrm{Y}^{\mathrm{NA}}$ and $\mathrm{Y}^{\mathrm{A}}$ refer to income reported respectively by non-audited and audited taxpayer.

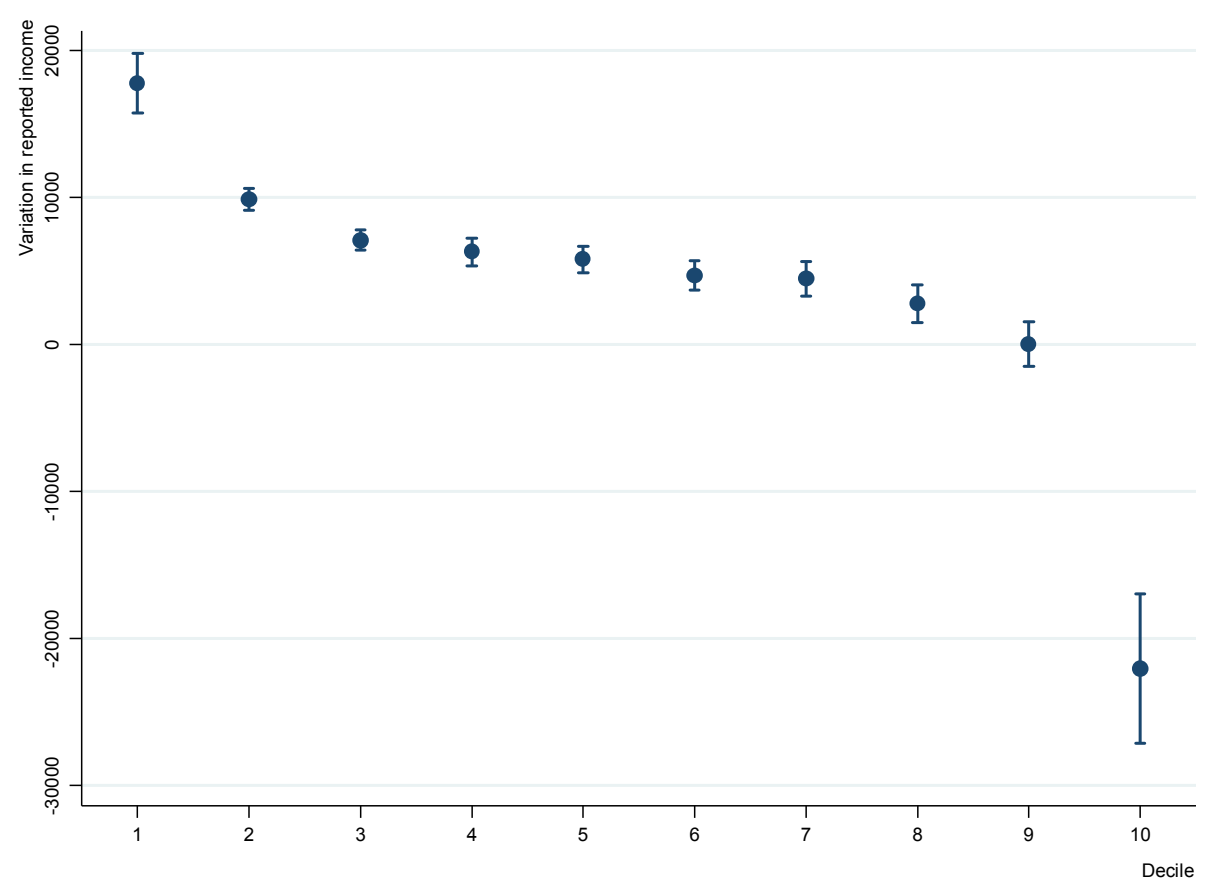

FIGURE 4- AUDIT EFFECT BY REPORTED INCOME DECILE 


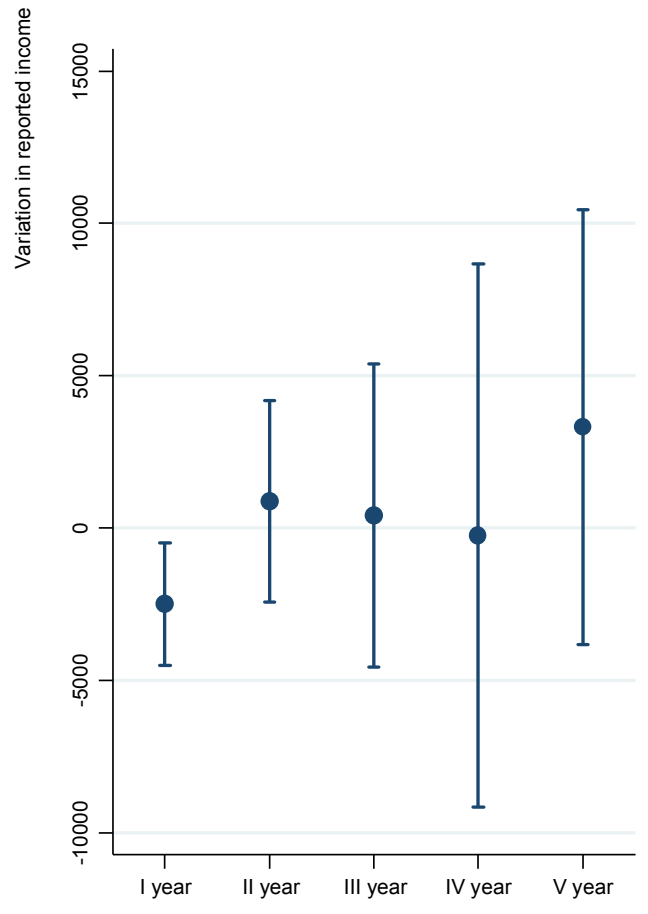

Null outcome audit

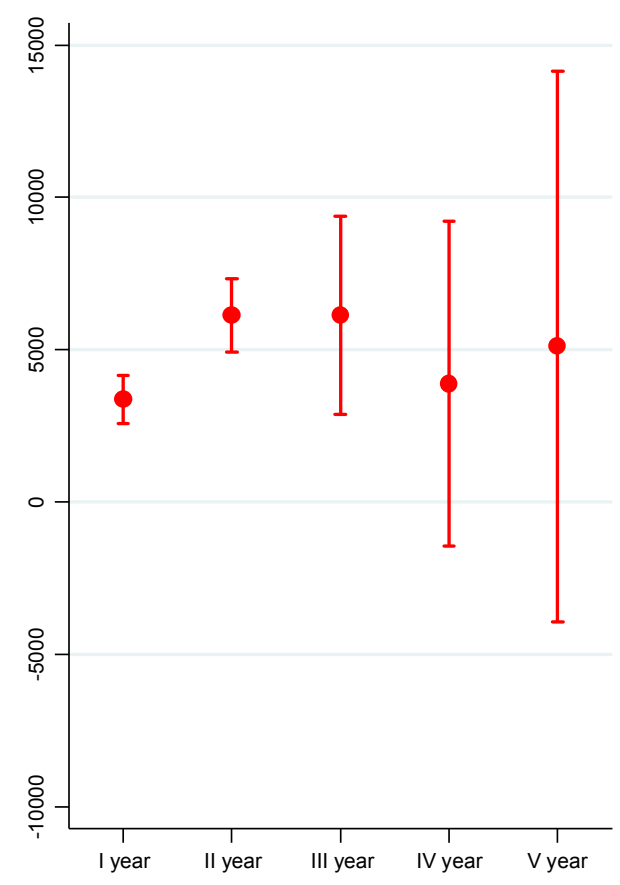

Positive assessment audit

FIGURE 5- DYNAMIC AUDIT EFFECT BY AUDIT OUTCOME

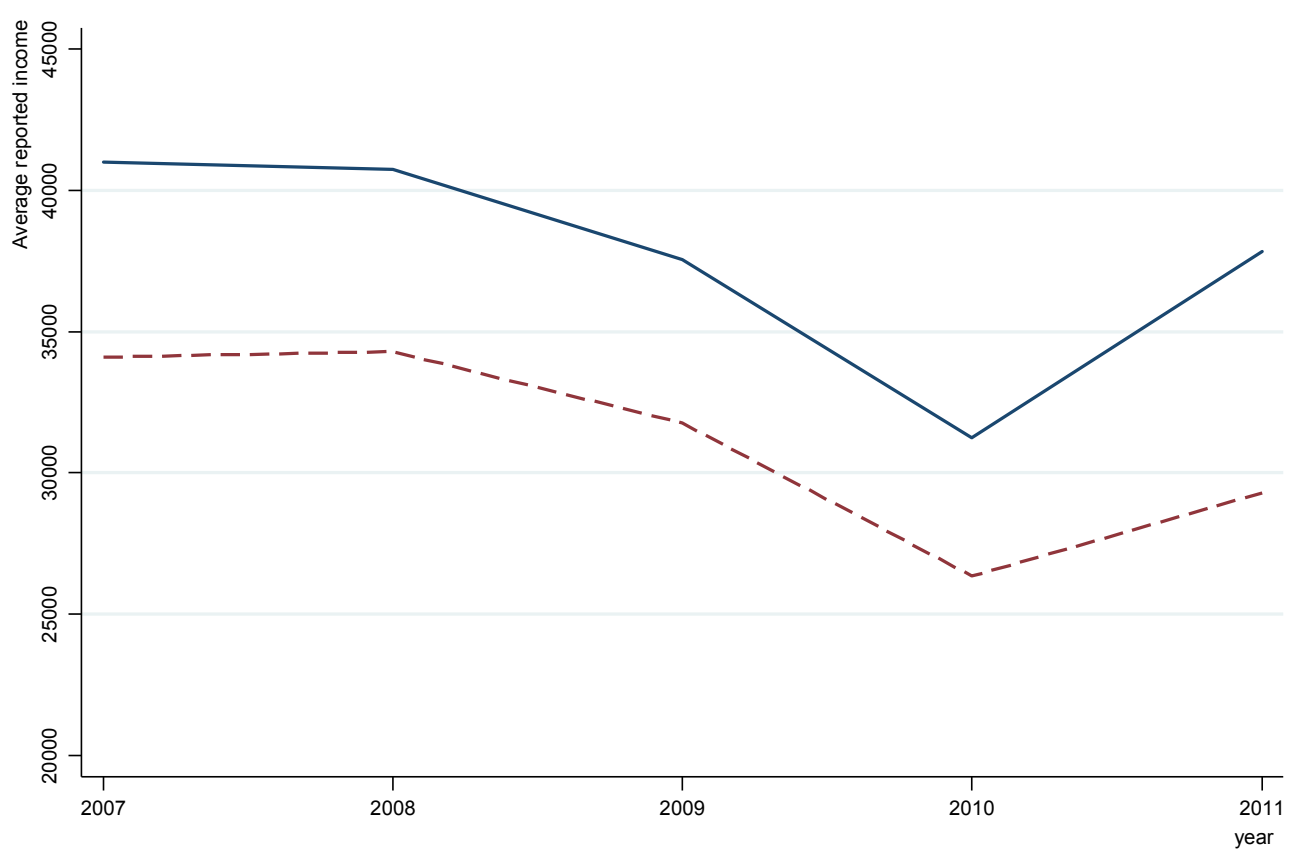

Audited taxpayers - - - - Non-audited taxpayers

FIGURE 6- THE COMMON TREND ASSUMPTION

Notes: The sample of audited taxpayers is restricted to taxpayers audited in 2012 (year after treatment=2011) to exclude effects of potential pre-2007 audits. 